\title{
The transpiration and respiration as mechanisms of water loss in cold storage of figs
}

\author{
Lentzou D., "Xanthopoulos G., Templalexis C. and Kaltsa A. \\ Department of Natural Resources Management and Agricultural Engineering, Faculty of School of \\ Environment and Agricultural Engineering, Agricultural University of Athens, 75 Iera Odos Str., 11855, \\ Athens, Greece
}

\author{
Article history: \\ Received: 12 March 2021 \\ Received in revised form: 22 \\ April 2021 \\ Accepted: 28 June 2021 \\ Available Online: 5 \\ December 2021
}

\section{Keywords:}

Water loss,

Figs,

Cold storage,

Transpiration rate,

Respiration rate,

Water vapour pressure deficit

DOI:

https://doi.org/10.26656/fr.2017.5(6).178

\begin{abstract}
Transpiration and respiration are two mechanisms of water loss in fresh agricultural products, resulting in visual and texture degradation. Neglecting respiration as a mechanism of water loss may lead to erroneous results at saturation where water vapour pressure deficit is zero and thus water loss is expected to be zero, however, the existence of a finite water loss is noted. In this context, an analysis of the associated with transpiration and respiration water loss in figs (Ficus carica L.) was carried out at $0^{\circ} \mathrm{C}$, $10^{\circ} \mathrm{C}$ and $20^{\circ} \mathrm{C}$ and $45.64 \%, 80.22 \%$ and $98.65 \%$ relative humidity as well as the air conditions of walk-in cold storage rooms. The estimated transpiration rate ranged between 0.11-1.416 mg cm $\mathrm{m}^{-2} \mathrm{~h}^{-1}$ for a water vapour pressure deficit of 0.0-0.98 $\mathrm{kPa}$. The water vapour pressure deficit estimation was based on the difference between cold air temperature and figs' surface temperature. The respiration rate was calculated at $0^{\circ} \mathrm{C}$, $10^{\circ} \mathrm{C}$ and $20^{\circ} \mathrm{C}$ as $0.47 \pm 0.08,0.94 \pm 0.11$ and $2.69 \pm 0.17 \mathrm{~mL}_{\mathrm{CO} 2} 100 \mathrm{~g}^{-1} \mathrm{~h}^{-1}$. Quantification of the water loss showed that at $20^{\circ} \mathrm{C}$ and saturation, the water loss due to respiration accounts for $3.9 \%$ of the respective water loss due to water vapour pressure deficit while on average, the water loss due to respiration accounts for $1.5 \%, 2.1 \%$ and $2.6 \%$ of the water loss due to water vapour pressure deficit at $0^{\circ} \mathrm{C}, 10^{\circ} \mathrm{C}$ and $20^{\circ} \mathrm{C}$.
\end{abstract}

\section{Introduction}

The food supply chain is characterised by a high rate of losses, with the highest, taking place between harvest and consumption. About $45-55 \%$ of the global fruit and vegetable production is lost or becomes unsalable along the value chain from production to consumption as compared to $35 \%, 30 \%$ and $20 \%$ for seafood, cereals and meats, respectively (Gustavsson, 2011; Lipinski et al., 2013). Water loss in fruits and vegetables takes place after harvest is driven by the mechanisms of transpiration and respiration, but unlike the mother plant, cannot be replaced from the root-soil system. Water loss, causes visual degradation, firmness loss and succulence due to shrivelling which are associated with marketable loss. There is a scarcity of recent information on the critical limits of water loss in fruits, however, Ben-Yehoshua and Rodov (2003) reported that water loss of 3-10\% of their initial weight initiates wilting and makes products non-marketable. To extend the shelf-life of perishable products, the water loss must be controlled by applying appropriate packaging, waxing and optimal storage conditions (temperature and relative humidity). The direct and indirect impact of water loss on the quality of the harvested produce has been widely studied and reported, however, the water loss mechanism has been accepted as a complex process that is driven by many factors regarding the physiological, biochemical and physico-mechanical properties of the product as well as the production, harvest and postharvest treatments and handling (Lufu et al., 2020). Transpiration has been considered as the most significant water loss mechanism, however, is widely reported, neglecting respiration as also a mechanism of water loss. Factors affecting the transpiration rate of fresh fruits and vegetables have been categorized as intrinsic, such as surface-to-volume or surface-to-mass ratio, surface injuries, morphological and anatomical characteristics (cuticular wax, cracks, lenticels), maturity stage, and extrinsic, such as air temperature, relative humidity and air velocity. Many researchers (Caleb et al., 2012; Caleb et al., 2013; Bovi et al., 2016; Bovi et al., 2018) have reported that water evaporation from the produce surface is due to water vapour deficit and the associated respiratory activity. Respiration is the oxidative breakdown of complex 
substrate molecules (starch, sugars organic acids) into simpler $\left(\mathrm{CO}_{2}, \mathrm{H}_{2} \mathrm{O}\right)$ with the concurrent thermal and intermediate molecules production which sustains the numerous anabolic reactions essential for the maintenance of cellular organization and membrane integrity of living cells (Kader and Saltveit, 2003). Respiration is affected by a series of factors that can be categorized into internals (type of product, genotype, maturity, climacteric, chemical consistency) and externals (temperature, $\mathrm{O}_{2}$ and $\mathrm{CO}_{2}$ levels in the storage atmosphere, $\mathrm{C}_{2} \mathrm{H}_{4}$ levels especially in climacteric fruits, wounds and bruises in combination with high storage temperatures). Lufu et al. (2020) conducted an exhaustive review on the water loss of fruits and the factors that affect it in the pre-and post-harvest stage. From this study can be seen that there is a lack of information regarding certain high-value fruits such as figs. Fresh figs are among the ten healthiest fruits (apple, blueberry, avocado, banana, grape, kiwi, orange, pomegranate, mango, papaya) and as highly perishable have very short storage and shelf life. Therefore the application of optimum storage conditions is of utmost importance. Delayed cold storage, can cause water loss that can exceed 5\% within a few hours before cold storage (Dollahite et al., 2007).

The objectives of this study are the analysis and quantification of the water loss in fresh whole figs due to the transpiration and respiration mechanisms and modelling of transpiration rate regarding storage temperature, relative humidity and storage time as well the respiration rate regarding the storage temperature. Based on the stoichiometric analysis, the water loss due to oxidative respiration is estimated and compared to the water loss related to water vapour pressure deficit. Finally, the peel mass transfer coefficient is calculated for the range of the tested experimental conditions.

\section{Materials and methods}

\subsection{Raw materials}

Figs (Ficus carica L. var. Tsapela) were obtained from a local farmer in southern Peloponnese, Greece. The fruits were picked based on their maturity to ensure uniformity. The initial average mass was $41.91 \pm 3.7 \mathrm{~g}$ and the respective volume $34.77 \pm 3.3 \mathrm{~cm}^{3}$. The fruits were transported to the laboratory under refrigerated conditions where defective fruits were discarded and the remaining fruits were cleaned thoroughly with kitchen tissue. No pre-treatment was applied.

\subsection{Experimental setup}

The experimental setup (Figure 1) consisted of nine plastic containers $(70 \mathrm{~L}$ each) placed in three walk-in cold storage rooms $\left(16 \mathrm{~m}^{3}\right.$ each $)$. Three storage

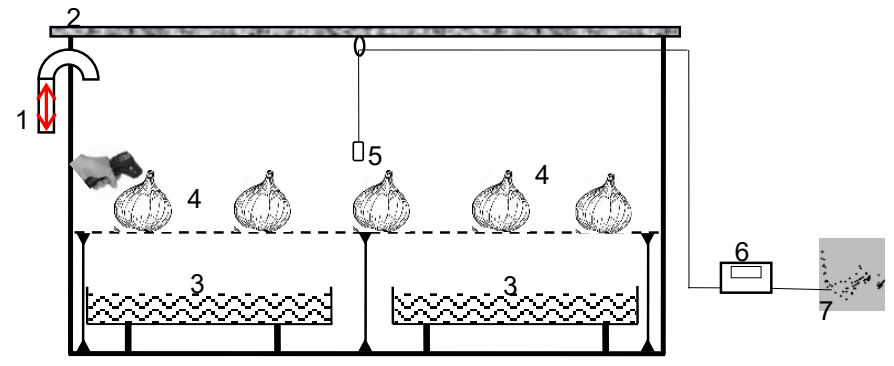

Figure 1. The experimental setup for mass loss measuring of figs during cold storage. 1: air exchange, 2: lid, 3: salt solutions, 4: figs on top of the wire mesh, 5: hydro-thermal sensor, 6: data logger, 7: laptop.

temperatures were tested $0^{\circ} \mathrm{C}, 10^{\circ} \mathrm{C}$ and $20^{\circ} \mathrm{C}$ and three relative humidity levels $45.64 \pm 1.1, \quad 80.22 \pm 1.05$, $98.65 \pm 3.9 \%$ along with the air relative humidity of the walk-in cold storage rooms $(75.72 \pm 1.3 \%)$ served as a measure of the efficacy of the tested semi-empirical model for water loss prediction. The relative humidity in the containers was regulated by the static method of saturated salts such as magnesium chloride $\left(\mathrm{MgCl}_{2}\right)$ for the low relative humidity and sodium chloride $(\mathrm{NaCl})$ for the high relative humidity while saturation was simulated by deionised water according to Greenspan (1977). The relative humidity levels in the containers were found increased by $10-12 \%$ approximately, than those reported by Greenspan (1977) due to the number of the tested samples per container and the accumulated water vapour. Salt solutions were placed in two large glass pans (Figure 1) covering the base of the container, under a wire mesh serving as the supporting frame where the samples were placed on it sufficiently apart. The containers were equipped with a small diameter tube communicated with the cold storage environment to ensure that the internal composition $\left(\mathrm{O}_{2}\right.$ and $\left.\mathrm{CO}_{2}\right)$ of the atmosphere is not affected by the respiration of the fig samples. The experimental setup has been tested in previous experiments (Xanthopoulos et al., 2014; Xanthopoulos et al., 2017) and proved to prevent the establishment of anoxic conditions and temperature stratification in the containers. The internal atmosphere of the containers was monitored by a headspace gas analyser (CheckMate 9000, PBI Dansensor Co., Denmark). The weighing of the samples in each of the three walk-in cold storage rooms was carried out by an electronic balance to ensure that weighing was not prone to errors due to water condensation on the surface of the sample. Opening of the plastic containers' lid before weighing was carried out with great caution to ensure minimum disturbance of the internal atmosphere. The air temperature and relative humidity in the plastic containers were recorded by a network of hygro-thermal sensors (Xanthopoulos et al., 2014). Before samples' weighing, their surface temperature was measured by an infrared thermometer (Kiray 100, KIMO Instruments, 
France) having accuracy $\pm 2.5^{\circ} \mathrm{C}\left(-50^{\circ} \mathrm{C}\right.$ to $\left.20^{\circ} \mathrm{C}\right)$, and infrared repeatability $\pm 1.3^{\circ} \mathrm{C}\left(-50^{\circ} \mathrm{C}\right.$ to $\left.20^{\circ} \mathrm{C}\right)$. The water activity $\left(\mathrm{a}_{\mathrm{w}}\right)$ was measured by the HygroLab $\mathrm{C} 1$ (Rotronic AG, Bassersdorf, Schweiz) equipped with a measurement sensor HC2-AW. Prior to the measurements of $a_{w}$ the measurement, the sensor was calibrated in the area of $\mathrm{a}_{\mathrm{w}}$ : 0.65-0.95 using SCS certified humidity standards.

\subsection{Experimental procedure}

Five samples were tested at 3 humidity levels and 3 storage temperatures in three plastic containers (Figure 1) of constant relative humidity per tested temperature and 5 samples were stored unpackaged in the three walkin cold storage rooms (in total 60 samples). The temperature in the cold storage rooms was set at $0^{\circ} \mathrm{C}$, $10^{\circ} \mathrm{C}$ and $20^{\circ} \mathrm{C}$ within $\pm 1.0^{\circ} \mathrm{C}$. Based on previous experimental studies (Xanthopoulos et al., 2014; Xanthopoulos et al., 2017) the experimental setup establishes homogeneous conditions in the plastic containers and no significant moisture stratification was noted. The weighing of the samples was carried out at predefined time intervals. The duration of the experimental runs varied according to the storage temperature and was 8 days at $0^{\circ} \mathrm{C}, 6$ days at $10^{\circ} \mathrm{C}$ and 4 days at $20^{\circ} \mathrm{C}$. Transpiration rate was expressed per unit surface area as $\mathrm{mg} \mathrm{cm}^{-2} \mathrm{~h}^{-1}$ (Equation 1a) as well as per unit of initial mass as $\mathrm{g} \mathrm{kg}^{-1} \mathrm{~h}^{-1}$ (Equation $1 \mathrm{~b}$ ).

$$
\begin{aligned}
\mathrm{TR}_{\mathrm{s}} & =\frac{1000 \times\left(M_{\mathrm{i}}-\mathrm{M}_{\mathrm{t}}\right)}{\mathrm{t} \times \mathrm{A}_{\mathrm{s}}} \\
\mathrm{TR}_{\mathrm{m}} & =\frac{\mathrm{M}_{\mathrm{i}}-\mathrm{M}_{\mathrm{t}}}{\mathrm{t} \times\left(\mathrm{M}_{\mathrm{i}} / 1000\right)}
\end{aligned}
$$

where $\mathrm{TR}_{\mathrm{s}}$ is the transpiration rate per unit surface area of the product in $\mathrm{mg} \mathrm{cm} \mathrm{cm}^{-2}$ and $\mathrm{TR}_{\mathrm{m}}$ is the transpiration rate per unit of initial mass of the product in $\mathrm{g} \mathrm{kg}^{-1} \mathrm{~h}^{-1}, \mathrm{M}_{\mathrm{i}}$ is the initial mass $(\mathrm{g}), \mathrm{M}_{\mathrm{t}}$ is the mass of the product $(\mathrm{g})$ at time $\mathrm{t}(\mathrm{h})$ and $\mathrm{A}_{\mathrm{s}}$ the surface area of the product $\left(\mathrm{cm}^{2}\right)$.

The water activity was estimated by the dynamic method on five figs stored unpackaged at $20^{\circ} \mathrm{C}$ and $75.72 \pm 1.3 \%$ relative humidity. During predefined time intervals, the water activity was measured at $20^{\circ} \mathrm{C}$. The average $a_{w}$ was $0.932 \pm 0.035$. Water activity values for different agricultural products have been reported by Mahajan et al. (2008) for mushrooms, $0.984 \pm 0.01$, Sousa -Gallagher et al. (2013) for strawberries, $0.984 \pm 0.003$, Caleb et al. (2013) for pomegranate arils, $0.984 \pm 0.01$ and Xanthopoulos et al. (2017) for pears, $0.924 \pm 0.05$. Based on the estimated $\mathrm{a}_{\mathrm{w}}$ and the tested conditions ( $\mathrm{T}$, $\mathrm{RH})$, water vapour pressure deficit (WVPD $\left.=\mathrm{P}_{\mathrm{vs}}-\mathrm{P}_{\mathrm{va}}\right)$ was calculated according to Xanthopoulos et al. (2012a), where $\mathrm{P}_{\mathrm{vs}}$ is the water vapour pressure at the surface of the product based on the surface temperature and $\mathrm{P}_{\mathrm{va}}$ is the water vapour pressure of the surrounding air.

Respiration rate $\left(\mathrm{CO}_{2}\right.$ production) was estimated employing the patented portable experimental setup (RICKLOS) (Mitropoulos et al. 2000). The RICKLOS is a closed-static respiration system in which the accumulated $\mathrm{CO}_{2}$ is measured by a Riken Keiki RI-411Á (RKI Instruments, Japan) having accuracy $\pm 2 \%$ and resolution $25 \mathrm{ppm}_{\mathrm{CO} 2}$. The measurement of respiration rate was taken place at three samples. The samples were taken out of the containers at predefined times and placed in the respiration cells.

Slatnar et al. (2011) and Pereira et al. (2017) reported that figs respiration can be described by glucose oxidation or its isomer fructose since the remaining sugars are of limited quantity. In particular, Slatnar et al. (2011) reported that fructose accounts for $\approx 52 \%$, glucose for $\approx 46 \%$ and sucrose is less than $2 \%$, which is in accordance with Veberic et al. (2008) results. Since glucose and fructose share the same chemical formula $\left(\mathrm{C}_{6} \mathrm{H}_{12} \mathrm{O}_{6}\right)$ and stoichiometric equation for aerobic oxidation, therefore, as the metabolic substrate of the aerobic respiration of figs was assumed the sum of glucose and sucrose. Scarce information is found in the literature regarding the fresh figs concentration in total sugars or in glucose, sucrose and fructose. Therefore, literature data by Pereira et al. (2017) were adopted in the present study. The sum of glucose and fructose in figs (average values) was taken as $12.17 \mathrm{~g}_{\text {sugar }} 100 \mathrm{~g}^{-1}$ fig $\left(6.35 \mathrm{~g}_{\text {fructose }} 100 \mathrm{~g}^{-1}\right.$ fig and $5.82 \mathrm{~g}_{\text {glucose }} 100 \mathrm{~g}^{-1}$ fig $)$. The stoichiometric oxidation of fructose and glucose is described as:

$$
\mathrm{C}_{6} \mathrm{H}_{12} \mathrm{O}_{6}+6 \mathrm{O}_{2} \rightarrow 6 \mathrm{CO}_{2}+6 \mathrm{H}_{2} \mathrm{O}+2,835.3 \mathrm{~kJ}
$$

The heat release per mole of the oxidised substrate (Equation 2) was assumed as the average heat release from glucose and fructose. Based on Equation 2, for every mole of substrate oxidised $\left(=180 \mathrm{~g}_{\text {sugar }}\right), 6$ moles of water $108 \mathrm{~g}_{\text {water }}$ and 6 moles of $\mathrm{CO}_{2} 6 \times 22,400 \mathrm{~mL}_{\mathrm{CO} 2}=$ $134.4 \times 10^{3} \mathrm{~mL}_{\mathrm{CO} 2}$ are released. Therefore based on the stoichiometric Equation 2 and the stoichiometric analogy, for every $100 \mathrm{~g}$ of fig, $12.17 \mathrm{~g}$ of the substrate (glucose and fructose) are oxidised, producing $\mathbf{A}=$ $108 \mathrm{~g}_{\text {water }} \times\left(12.17 \mathrm{~g}_{\text {sugar }} / 180 \mathrm{~g}_{\text {sugar }}\right)$ of water and $\mathbf{B}=$ $134.4 \times 10^{3} \mathrm{~mL}_{\mathrm{CO} 2} \times\left(12.17 \mathrm{~g}_{\text {sugar }} / 180 \mathrm{~g}_{\text {sugar }}\right)$ of $\mathrm{CO}_{2}$. Transforming the water and $\mathrm{CO}_{2}$ release into hourly rates (mathematical transformation) can represent the water loss due to respiration WL $\left(g_{\text {water }} \mathrm{kg}^{-1}{ }_{\text {fruit }} \mathrm{h}^{-1}\right)$ and RR $\left(\mathrm{mL}_{\mathrm{CO} 2} 100 \mathrm{~g}_{\text {fruit }}{ }^{-1} h^{-1}\right)$ respectively. Finally, by combing the WL with RR and rearranging, the following equation is derived.

$$
\mathrm{WL}=10 \times \mathbf{A} / \mathbf{B} \times \mathrm{RR}
$$

where WL is the water loss due to respiration $\left(g_{\text {water }} \mathrm{kg}^{-1}\right.$ fig $\left.{ }^{-1}\right), \mathrm{RR}$ is the respiration rate $\left(\mathrm{mL}_{\mathrm{CO} 2} 100 \mathrm{~g}_{\mathrm{fig}}\right.$ 
${ }^{1} h^{-1}$ ) and $\mathbf{A}$ and $\mathbf{B}$ are the coefficients from the previously stoichiometry.

The experiments were conducted according to a full factorial design, considering 3 factors (storage temperature, relative humidity and storage time) at three levels $\left(3^{2}\right)$ of storage temperature and relative humidity with five figs in each container and five extra figs stored unpackaged in the cold rooms. In total, 12 experimental runs were carried out with 60 samples. Statistical analysis of variance and nonlinear regression was carried out by Statgraphics 19 (Statpoint Technologies, VA, USA) at a significance level of $\mathrm{P} \leq 0.05$. Nonlinear regressions were carried out based on the LevenbergMarquardt optimisation algorithm (Mason et al., 2003).

\section{Results and discussion}

\subsection{Estimation of the surface area and the effective diameter}

Fruits and vegetables lose water through their peel and thus the higher the specific surface area (surface area to unit mass), the higher the water loss. This justifies the significance of expressing transpiration rate per unit area rather than per unit mass. At the end of the experiments, the figs' three diameters were measured, two longitudinal $(\mathrm{a}, \mathrm{b})$ and one axial (c) assuming that their geometry is close to ellipsoid. Based on the conducted measurements, their mass was 25.73-55.16 g, their volume $20.61-45.26 \mathrm{~cm}^{3}$ and their mean diameters were $\mathrm{a}=42.32 \pm 2.9 \mathrm{~mm}, \mathrm{~b}=44.61 \pm 2.9 \mathrm{~mm}, \mathrm{c}=31.83 \pm 2.5$ $\mathrm{mm}$. Since $\mathrm{a}$ and $\mathrm{b}$ diameters were close enough but sufficiently bigger than c diameter by $37 \%$, the figs were considered as oblate spheroids having $\mathrm{a}=\mathrm{b}>\mathrm{c}$. The estimated areas of the figs' surface were associated with their respective mass (mg) according to the following equation:

$$
\mathrm{A}_{\mathrm{s}}=\mathrm{b} \times \mathrm{M}^{\mathrm{d}}
$$

where, $A_{s}$ is the surface area of figs $\left(\mathrm{cm}^{2}\right), M$ the mass of figs $(\mathrm{mg})$ while $b$ and $d$ the parameters of Equation $4 \mathrm{a}$, calculated from the non-linear regression and found respectively as $0.0041 \pm 0.0002$ and $0.68 \pm 0.01$, where $\mathrm{R}_{\text {adj }}^{2}=0.92$ and $\mathrm{SEE}=1.44(\mathrm{P} \leq 0.05)$.

The effective figs' radius $(\mathrm{cm})$ was associated with the respective mass (mg) as follows:

$$
r_{e}=\exp (-0.5726+0.3407 \times \operatorname{lnM})
$$

where $\mathrm{R}_{\text {adj }}^{2}=0.91$ and $\mathrm{SEE}=0.016(\mathrm{P} \leq 0.05)$.

\subsection{Estimation of mass loss and transpiration rate}

The water loss of the figs' was expressed in a dimensionless form $\left(\mathrm{M}_{\mathrm{i}}-\mathrm{M}_{\mathrm{t}}\right) / \mathrm{M}_{\mathrm{i}}$. In Figure $2 \mathrm{a}$, the mass loss with the storage time at $0^{\circ} \mathrm{C}$ is plotted while similar variations were noted at $10^{\circ} \mathrm{C}$ and $20^{\circ} \mathrm{C}$ for the three tested relative humidity levels. In this case, the water loss was found less than $4 \%$ in the cases of $98.65 \%$ and $80.22 \%$ while $12 \%$ water loss was found in the lower relative humidity $45.64 \%$. The temperature effect on mass loss is presented in Figure $2 b$ for the experimental case of $80.22 \%$ relative humidity and for the three storage temperatures $\left(0^{\circ} \mathrm{C}, 10^{\circ} \mathrm{C}, 20^{\circ} \mathrm{C}\right)$. At $80.22 \%$ relative humidity the water loss was $4.0 \%$ at $0^{\circ} \mathrm{C}, 5.0 \%$ at $10^{\circ} \mathrm{C}$ and $8.0 \%$ at $20^{\circ} \mathrm{C}$. A similar range of water loss was reported during cold storage $\left(0^{\circ} \mathrm{C}\right)$ of Brown Turkey and Kadota figs varieties (Crisosto et al., 2011).
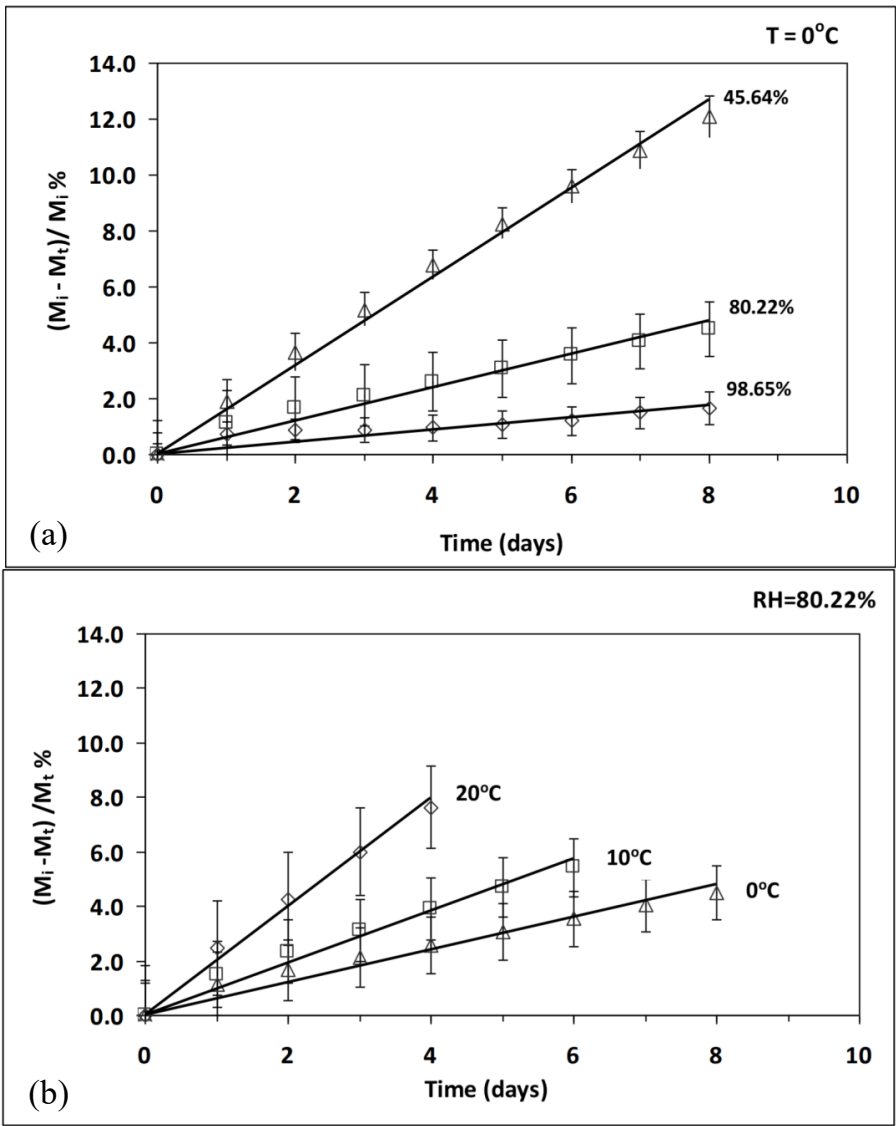

Figure 2. Reduced mass loss of figs with storage time. The effect of relative humidity (a) and storage temperature (b) are presented. Each point is the average of $n=5$ samples. Error bars are the standard deviation WL values.

Transpiration rate, and thus mass loss, was found to be higher at $45.64 \%$ and $20^{\circ} \mathrm{C}(\mathrm{WVPD}=0.98 \pm 0.01 \mathrm{kPa})$ and lower at $98.65 \%$ and $0^{\circ} \mathrm{C}, 10^{\circ} \mathrm{C}$ and $20^{\circ} \mathrm{C}($ WVPD $=$ $0.0 \mathrm{kPa}$ ). Although in cases 1, 4, and 7 (cf. in Figure 3), the water vapour pressure deficit is zero, the observed variation in the respective transpiration rates among the three cases could be respiration driven, since the latter is also considered in the transpiration rate calculation, and as will be following analysed, their ranking follows the respective respiration rate ranking which is $\left.\mathrm{RR}\right|_{200 \mathrm{C}}>\left.\mathrm{RR}\right|_{10 \mathrm{oC}}>\left.\mathrm{RR}\right|_{0_{0} \mathrm{C}}$; respiration is controlled from storage temperature and the physiology of the fruit (climacteric, maturity stage). Figure 3 highlights the significance of air temperature in transpiration rate and the consequent water loss in the stored fresh figs. Thus, 
regardless of the air relative humidity in the cold storage rooms, as the air temperature (cf. to cases 9, 6 and 3 in Figure 3) decreases, decreases respectively the transpiration rate. The previous behaviour has been discussed by Sastry and Buffington (1982; 1983), who assumed that it originated from the surface temperature which under saturated conditions rises above the ambient temperature causing an increase in $\mathrm{P}_{\mathrm{vs}}$ and therefore a finite moisture loss may exist even at these storage conditions. In the present study, the figs' surface temperature was measured by an IR thermometer during the experiments and was found that the difference between the air temperature and figs' surface temperature ranged at $0^{\circ} \mathrm{C}$ between $1.8-3.4^{\circ} \mathrm{C}$, at $10^{\circ} \mathrm{C}$ between $0.9-1.3^{\circ} \mathrm{C}$ and $20^{\circ} \mathrm{C}$ between $0.2-0.6^{\circ} \mathrm{C}$. The temperature difference between figs' surface and cold storage room air was the lowest in the saturation case where relative humidity was $98.65 \%$ and the highest in the lowest relative humidity case where relative humidity was $45.64 \%$. In each of the tested experimental cases, the $\mathrm{TR}_{\mathrm{s}}$ and $\mathrm{TR}_{\mathrm{m}}$ were calculated based on Equations $1 \mathrm{a}$ and 1b. The $\mathrm{TR}_{\mathrm{s}}\left(\mathrm{mg} \mathrm{cm}^{-2} \mathrm{~h}^{-1}\right)$ increased with WVPD $(\mathrm{kPa})$ and this trend is presented in Figure 3 where the WVPD ranges between 0.0 and $0.98 \mathrm{kPa}$ and the highest value was found in the case of $20^{\circ} \mathrm{C}$ and $45.64 \%$ relative humidity.

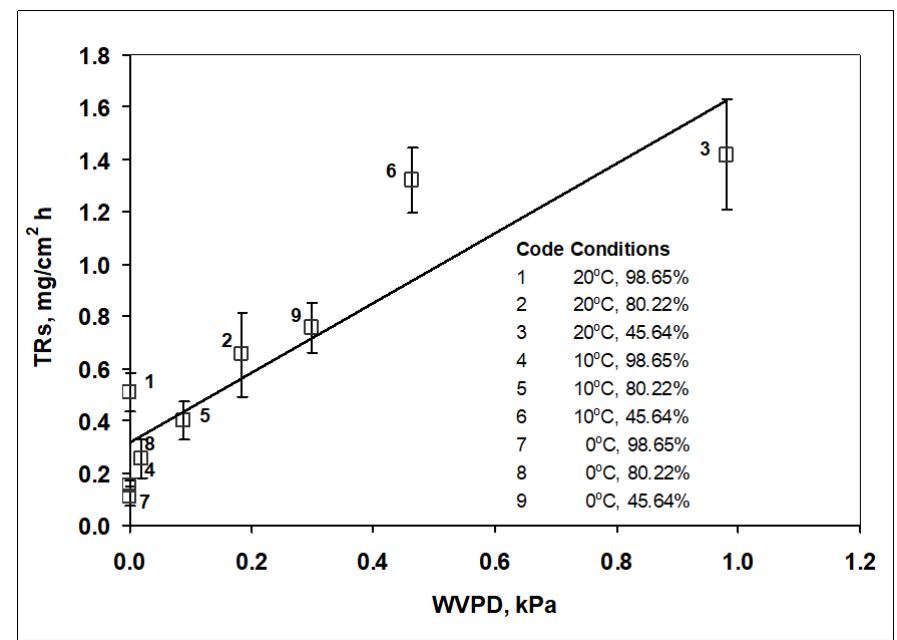

Figure 3. Estimated $\mathrm{TR}_{\mathrm{s}}$ values vs WVPD for all the tested cases. Each point is the average of $n=5$ samples over the storage period. Error bars are the standard deviation for $\mathrm{TR}_{\mathrm{s}}$ values. For $\mathrm{WVPD}=0.0 \mathrm{kPa}, \mathrm{TR}_{\mathrm{s}}=0.322 \mathrm{mg} \mathrm{cm}^{-2} \mathrm{~h}^{-1}$.

The mean transpiration rate ranged from 0.11 to $1.416 \mathrm{mg} \mathrm{cm}^{-2} \mathrm{~h}^{-1}$ or 0.13 to $1.513 \mathrm{~g} \mathrm{~kg}^{-1} \mathrm{~h}^{-1}$ respectively. Mahajan et al. (2008) reported transpiration rates, $\mathrm{TR}_{\mathrm{s}}$ for mushrooms of 0.14 to $2.5 \mathrm{mg} \mathrm{cm}^{-2} \mathrm{~h}^{-1}$ or $\mathrm{TR}_{\mathrm{m}}$ : 0.29 $5.2 \mathrm{~g} \mathrm{~kg}^{-1} \mathrm{~h}^{-1}$ (tested conditions: $4^{\circ} \mathrm{C}, 10^{\circ} \mathrm{C}, 16^{\circ} \mathrm{C}$ and $76 \%$, 86\%, 96\%). Caleb et al. (2013) reported $\mathrm{TR}_{\mathrm{m}}$ values for pomegranate arils of 0.047 to $0.698 \mathrm{~g} \mathrm{~kg}^{-1} \mathrm{~h}^{-1}$ (tested conditions: $5^{\circ} \mathrm{C}, 10^{\circ} \mathrm{C}, 15^{\circ} \mathrm{C}$ and $76 \%, 86 \%$, $96 \%$ ). Sousa-Gallagher et al. (2013) reported $\mathrm{TR}_{\mathrm{m}}$ values for strawberries of 0.24 to $1.16 \mathrm{~g} \mathrm{~kg}^{-1} \mathrm{~h}^{-1}$ (tested conditions: $5^{\circ} \mathrm{C}, 10^{\circ} \mathrm{C}, 15^{\circ} \mathrm{C}$ and $76 \%, 86 \%, 96 \%$ ). Xanthopoulos et al. (2014) reported $\mathrm{TR}_{\mathrm{s}}$ for grape tomatoes in the range of 0.012 to $0.058 \mathrm{mg} \mathrm{cm}^{-2} \mathrm{~h}^{-1}$ or $\mathrm{TR}_{\mathrm{m}}$ : $0.018-0.107 \mathrm{~g} \mathrm{~kg}^{-1} \mathrm{~h}^{-1}$ (tested conditions: $10^{\circ} \mathrm{C}$, $15^{\circ} \mathrm{C}, 20^{\circ} \mathrm{C}$ and $\left.70 \%, 80 \%, 92 \%\right)$. Xanthopoulos et al. (2017) reported $T_{\mathrm{s}}$ for pears in the range of 0.030 to $0.283 \mathrm{mg} \mathrm{cm}{ }^{-2} \mathrm{~h}^{-1}$ or $\mathrm{TR}_{\mathrm{m}}: 0.025-0.258 \mathrm{~g} \mathrm{~kg}^{-1} \mathrm{~h}^{-1}$ (tested conditions: $0^{\circ} \mathrm{C}, 10^{\circ} \mathrm{C}, 20^{\circ} \mathrm{C}$ and $70 \%, 80 \%, 95 \%$ ). Bovi et al. (2018) reported $\mathrm{TR}_{\mathrm{m}}$ values for strawberries of 0.13 to $1.28 \mathrm{~g} \mathrm{~kg} \mathrm{k}^{-1} \mathrm{~h}^{-1}$ (tested conditions: $4^{\circ} \mathrm{C}, 12^{\circ} \mathrm{C}, 20^{\circ} \mathrm{C}$ and $76 \%, 86 \%, 96 \%)$. The significance of storage temperature and relative humidity in transpiration rate has been experimentally proved and analysed. In previous studies (Xanthopoulos et al., 2014; Xanthopoulos et al., 2017) was reported that transpiration rate increases as temperature increases and relative humidity decreases. In the present study, the transpiration rate increased by $\approx 90 \%$ with temperature increase from $10^{\circ} \mathrm{C}$ to $20^{\circ} \mathrm{C}$ while transpiration rate decreased by $\approx 38.5 \%$ with relative humidity increase from $80.22 \%$ to $98.65 \%$ (cf. Figure 3). Similarly, increasing the relative humidity in the container from $45.64 \%$ to $98.65 \%$ caused a decrease of the transpiration rate by 6 times at $0^{\circ} \mathrm{C}$ (suggested storage temperature) whereas temperature decrease from $20^{\circ} \mathrm{C}$ to $0^{\circ} \mathrm{C}$ decreased transpiration rate by 3 times at $80.22 \%$ relative humidity. A similar response in their experiments has been reported by Mahajan et al. (2008), Caleb et al. (2013) and Sousa-Gallagher et al. (2013). Veraverbeke et al. (2003) reported that reducing the relative humidity during apples cold storage from $97.5 \%$ to $95 \%$ resulted in a $30 \%$ increase in moisture loss. Experimental observations showed that the tested figs exhibited limited deformation when mass loss exceeded the limit of 4.0$5.0 \%$ of their initial mass, which is consistent with BenYehoshua and Rodov (2003) report, regarding the visual and texture degradation in fruits and vegetables when 3$10 \%$ mass loss is noted.

\subsection{Modelling and validation of transpiration rate}

The semi-empirical model for $\mathrm{TR}_{\mathrm{m}}\left(\mathrm{g} \mathrm{kg}^{-1} \mathrm{~h}^{-1}\right)$ estimation, proposed by Xanthopoulos et al. (2014) and based on Fick's law of diffusion, was used to model figs' water loss. The employed model accounts for the temperature effect on mass transfer coefficient $K_{i}^{\prime}$ :

$$
T R_{m}=\frac{M_{i}-M_{t}}{t \times\left(\frac{M_{i}}{1000}\right)}=K_{i}^{\prime} \exp \left[-\frac{E_{a}}{R}\left(\frac{1}{T}-\frac{1}{T_{r}}\right)\right] \times\left(a_{w}-\frac{R H}{100}\right)
$$

were $\mathrm{TR}_{\mathrm{m}}$ is the transpiration rate $\left(\mathrm{g} \mathrm{kg}^{-1} \mathrm{~h}^{-1}\right)$ per unit of initial mass, $M_{i}$ is the initial mass of the product $(\mathrm{g})$, $\mathrm{M}_{\mathrm{t}}$ is the mass of the product at time $\mathrm{t}(\mathrm{g}), \mathrm{t}$ is the storage time $(\mathrm{h}), \mathrm{K}_{\mathrm{i}}$ is the pre-exponential mass transfer coefficient $\left(\mathrm{g} \mathrm{kg}^{-1} \mathrm{~h}^{-1}\right), \mathrm{a}_{\mathrm{w}}$ is the water activity of the 
product, relative humidity is the relative humidity of the surrounding air (\%), $\mathrm{E}_{\mathrm{a}}$ is the activation energy $\left(\mathrm{J} \mathrm{mol}^{-1}\right)$, $\mathrm{R}$ is the gas constant $\left(\mathrm{J} \mathrm{mol}^{-1} \mathrm{~K}^{-1}\right)$, T is the absolute air temperature $(\mathrm{K})$ and $\mathrm{T}_{\mathrm{r}}$ is the reference temperature $(\mathrm{K})$. As reference temperature was taken the mean temperature from the three storage temperatures which was $283.15 \mathrm{~K}$. The $\mathrm{M}_{\mathrm{t}}$ values are obtained by solving Equation $5 b$ :

$$
M_{t}=M_{i}-K_{i}^{\prime} \exp \left[-\frac{E_{a}}{R}\left(\frac{1}{T}-\frac{1}{T_{r}}\right)\right] \times\left(a_{w}-\frac{R H}{100}\right) \times t \times\left(\frac{M_{i}}{1000}\right)
$$

The parameters of the previous model (Equation $5 \mathrm{~b}$ ) were calculated from the nonlinear regression as $\mathrm{K}_{\mathrm{i}}=$ $2.835 \mathrm{~g} \mathrm{~kg} \mathrm{k}^{-1} \mathrm{~h}^{-1}$ with confidence interval CIÎ(2.717, 2.953) and $\mathrm{E}_{\mathrm{a}}=33,190 \mathrm{~J} \mathrm{~mol}^{-1}$ with CIÎ( $\left.29,810,36,571\right)$, with good agreement between experimental and predicted data, $\mathrm{R}_{\text {adj }}^{2}=0.96, \mathrm{SEE}=0.82$ and mean absolute error $=0.61(\mathrm{P} \leq 0.05)$. The efficacy of the tested model (Equation 5b) was further evaluated from the mass loss of the unpackaged figs stored at $0^{\circ} \mathrm{C}, 10^{\circ} \mathrm{C}$ and $20^{\circ} \mathrm{C}$ and $75.72 \pm 1.3 \%$. The previous comparison showed that the tested model (Equation 5b) can predict efficiently (cf. Figure 4) the mass loss of the unpackaged figs within the range of the tested experimental conditions (storage temperatures and relative humidity). The calculated relative error from the comparison of the predicted with the experimental $\mathrm{M}_{\mathrm{t}}$ values was $0.5 \%$.

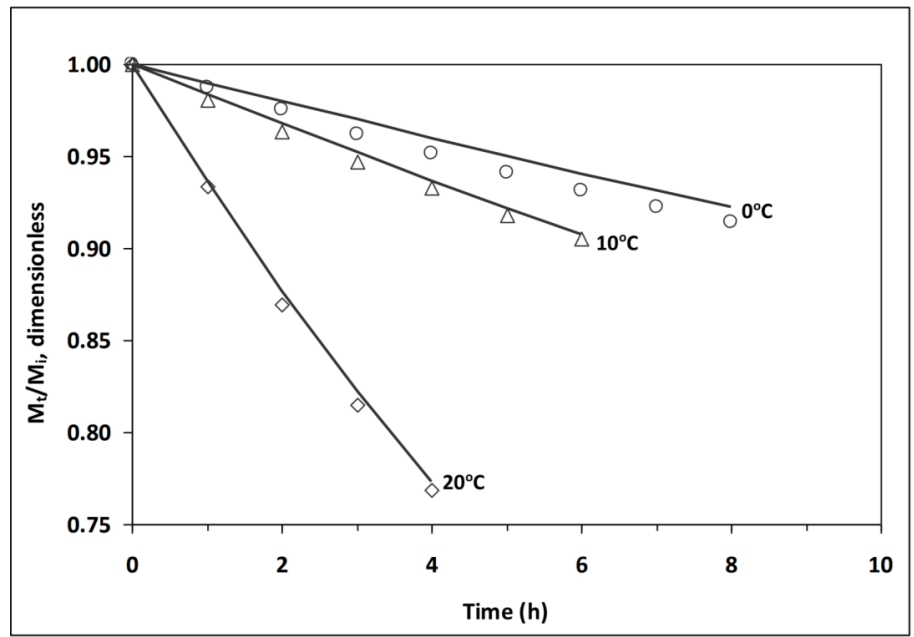

Figure 4. Experimental (points) and predicted (lines) from Equation $5 \mathrm{~b}$ values of mass loss for cold storage of unpackaged figs, $75.72 \pm 1.3 \%$. Each point is the average of $\mathrm{n}=$ 5 samples over the storage period, where mean initial mass for this case is $37.15 \pm 1.5 \mathrm{~g}$.

The model presented initially by Mahajan et al. (2008) regarding the $\mathrm{TR}_{\mathrm{s}}\left(\mathrm{mg} \mathrm{cm} \mathrm{cm}^{-2} \mathrm{~h}^{-1}\right)$ estimation and modified by Xanthopoulos et al. (2014), combines Newton's law of cooling with temperature dependence of mass transfer, as follows

$$
\frac{d V}{d t}=-K_{i}^{\prime} \exp \left[-\frac{E_{a}}{R}\left(\frac{1}{T}-\frac{1}{T_{r}}\right)\right] \times A_{s} \times\left(a_{w}-\frac{R H}{100}\right)
$$

where $\mathrm{V}$ is the volume of water lost from the product during transpiration $\left(\mathrm{cm}^{3}\right), \mathrm{t}$ is the storage time $(\mathrm{h})$, is the pre-exponential mass transfer coefficient $\left(\mathrm{cm} \mathrm{h}^{-1}\right)$ and $A_{s}$ is the surface area of the product $\left(\mathrm{cm}^{2}\right)$ estimated by Equation 4a. Substituting the volume of the lost water $K_{i}^{\prime}$ with the ratio $M_{t} / \rho_{w}\left(\rho_{w}=999.75 \mathrm{mg} \mathrm{cm}^{-3}\right.$, is the water density at $\mathrm{T}_{\mathrm{r}}$ ) and $\mathrm{A}_{\mathrm{s}}$ by Equation $4 \mathrm{a}$ and rearranging, yields

$$
-\frac{d M}{M^{b}}=d \times \rho_{w} \times K_{i}^{\prime} \exp \left[-\frac{E_{a}}{R}\left(\frac{1}{T}-\frac{1}{T_{r}}\right)\right] \times\left(a_{w}-\frac{R H}{100}\right) \times d t
$$

Following integration,

$$
M_{t}=\left[M_{i}^{1-b}+(b-1) \times d \times \rho_{w} \times K_{i}^{\prime} \exp \left[-\frac{E_{a}}{R}\left(\frac{1}{T}-\frac{1}{T_{r}}\right)\right] \times\left(a_{w}-\frac{R H}{100}\right) \times t\right]^{1 / 1-b b}
$$

The nonlinear regression of the experimental data with Equation 5e, derived the following: $\mathrm{K}_{\mathrm{i}}=0.171 \mathrm{~cm} \mathrm{~h}$ ${ }^{-1}$ with $\mathrm{CI} \in(0.164,0.178)$ and $\mathrm{E}_{\mathrm{a}}=28,610 \mathrm{~J} \mathrm{~mol}^{-1}$ with $\mathrm{CI} \in(25,368,31,851)$ having very good agreement between experimental and predicted data, $\mathrm{R}_{\text {adj }}^{2}=0.96$, $\mathrm{SEE}=0.80$ and mean absolute error $=0.58(\mathrm{P} \leq 0.05)$. The predicted $\mathrm{M}_{t}$ values (Equation $5 \mathrm{e}$ ) versus the experimental values are presented in Figure 5. As has been explained by Xanthopoulos et al. (2012b) the validity of the empirical models should be tested against the statistical hypotheses of homoscedasticity and residuals' normality. In the homoscedasticity hypothesis, residuals should exhibit a non-systematic pattern located around zero in a narrow value band. In the normality hypothesis, a normal probability plot consisting of an abscissa scaled for the predicted data and an ordinate scaled so as the cumulative distribution function of a normal distribution is plotted as a straight line should be used. The closer the predicted data are to the reference line, the more likely the residuals to follow a normal distribution. As can be seen in Figure 5 these two statistical hypotheses are adequately satisfied, which in turn shows that Equation $5 \mathrm{e}$ can be efficiently applied to

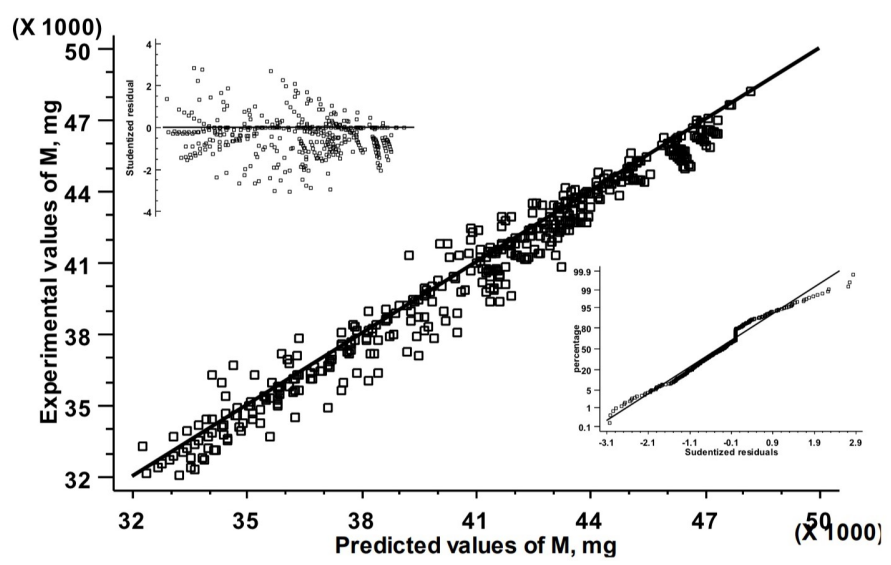

Figure 5. Experimental vs predicted (Equation 5e) mass of figs for all the tested cases. Upper left: studentised residuals plotted vs predicted mass loss values. Bottom right: normal probability of studentised residuals (studentised residual is the ratio of a residual divided by its standard deviation). 
predict water loss due to transpiration during cold storage of unpackaged figs within the range of the experimental conditions.

\subsection{Modelling of respiration rate of unpackaged figs}

Crisosto et al. (2011) reported that fresh figs produce very low amounts of carbon dioxide and in particular at $0^{\circ} \mathrm{C}, 0.2-0.4 \mathrm{~mL}_{\mathrm{CO} 2} 100 \mathrm{~g}^{-1} \mathrm{~h}^{-1}$, at $10^{\circ} \mathrm{C}, 0.9-1.2 \mathrm{~mL}_{\mathrm{CO} 2} 100 \mathrm{~g}$ ${ }^{-1} \mathrm{~h}^{-1}$ and at $20^{\circ} \mathrm{C}, 2.0-3.0 \mathrm{~mL}_{\mathrm{CO} 2} 100 \mathrm{~g}^{-1} \mathrm{~h}^{-1}$. Colelli et al. (1991) reported during cold storage of 'Mission' figs, respiration rates at $0^{\circ} \mathrm{C}, 0.2-0.5 \mathrm{~mL}_{\mathrm{CO} 2} 100 \mathrm{~g}^{-1} \mathrm{~h}^{-1}$ and at $5^{\circ} \mathrm{C}, 0.6-0.9 \mathrm{~mL}_{\mathrm{CO} 2} 100 \mathrm{~g}^{-1} \mathrm{~h}^{-1}$. In the present study, the average respiration rate of figs (Ficus carica L. var. Tsapela) was at $0^{\circ} \mathrm{C}$ as $0.47 \pm 0.08 \mathrm{~mL}_{\mathrm{CO} 2} 100 \mathrm{~g}^{-1} \mathrm{~h}^{-1}$, at $10^{\circ} \mathrm{C}$ as $0.94 \pm 0.11 \mathrm{~mL}_{\mathrm{CO} 2} 100 \mathrm{~g}^{-1} \mathrm{~h}^{-1}$ and at $20^{\circ} \mathrm{C}$ as $2.69 \pm 0.17 \mathrm{~mL}_{\mathrm{CO} 2} 100 \mathrm{~g}^{-1} \mathrm{~h}^{-1}$. Figure 6 , presents the respiration rate at $0^{\circ} \mathrm{C}$ and $45.64 \%, 80.22 \%$ and $98.65 \%$ relative humidity. As can be seen, figs stored at saturation exhibited the lowest respiration rate values while the other two cases had higher respiration rate values probably due to water stress driven by the WVPD in the different tested cases. The analysis of variance (ANOVA) of the respiration rate $\left(\mathrm{mL}_{\mathrm{CO} 2} 100 \mathrm{~g}^{-1} \mathrm{~h}^{-1}\right)$ with the experimental factors $(\mathrm{T}, \mathrm{RH}, \mathrm{t})$ is presented in Table $1(\mathrm{P} \leq 0.05)$. From Table 1 it is seen that the storage temperature and relative humidity affect significantly respiration rate $(\mathrm{P}<0.001)$ while transpiration rate is significantly affected by the relative humidity as has been previously discussed. The F-ratio in Table 1, analyzes the contribution of the storage temperature and relative humidity in respiration rate variation. In this case, the storage temperature has the highest by far Fratio indicating that this factor affects significantly respiration rate as was expected. The modelling of the respiration rate per storage temperature was carried out from an Arrhenius-type equation.

$$
R R=R_{\text {ref }} \times \exp \left[-\frac{E_{a}}{R}\left(\frac{1}{T}-\frac{1}{T_{r}}\right)\right]
$$

where $\mathrm{RR}$ is the mean respiration rate $\left(\mathrm{mL}_{\mathrm{CO} 2} 100 \mathrm{~g}^{-1} \mathrm{~h}\right.$ $\left.{ }^{-1}\right), \quad \mathrm{R}_{\mathrm{ref}}$ is the pre-exponential respiration rate $\left(\mathrm{mL}_{\mathrm{CO} 2} 100 \mathrm{~g}^{-1} \mathrm{~h}^{-1}\right), \mathrm{E}_{\mathrm{a}}$ is the energy of activation $\left(\mathrm{J} \mathrm{mol}^{-1}\right)$, $\mathrm{T}$ is the absolute air temperature $(\mathrm{K}), \mathrm{R}$ is the gas constant $\left(\mathrm{Jmol}^{-1} \mathrm{~K}^{-1}\right)$ and $\mathrm{T}_{\mathrm{r}}$ is the reference temperature (K) taken as $283.15 \mathrm{~K}$ (mean temperature of the three tested temperatures). From the nonlinear regression of the experimental data employing Equation 6, was calculated $\mathrm{R}_{\mathrm{ref}}=1.40 \mathrm{~mL}_{\mathrm{CO} 2} 100 \mathrm{~g}^{-1} \mathrm{~h}^{-1}$ with confidence interval CIÎ $(1.36,1.44)$ and $\mathrm{E}_{\mathrm{a}}=69,788 \mathrm{Jmol}^{-1}$ with CÎ̂ $(66,674,72,903)$, with good agreement between experimental and predicted data, $\mathrm{R}_{\text {adj }}^{2}=0.98, \mathrm{SEE}=0.13$ and mean absolute error $=0.10(\mathrm{P} \leq 0.05)$.

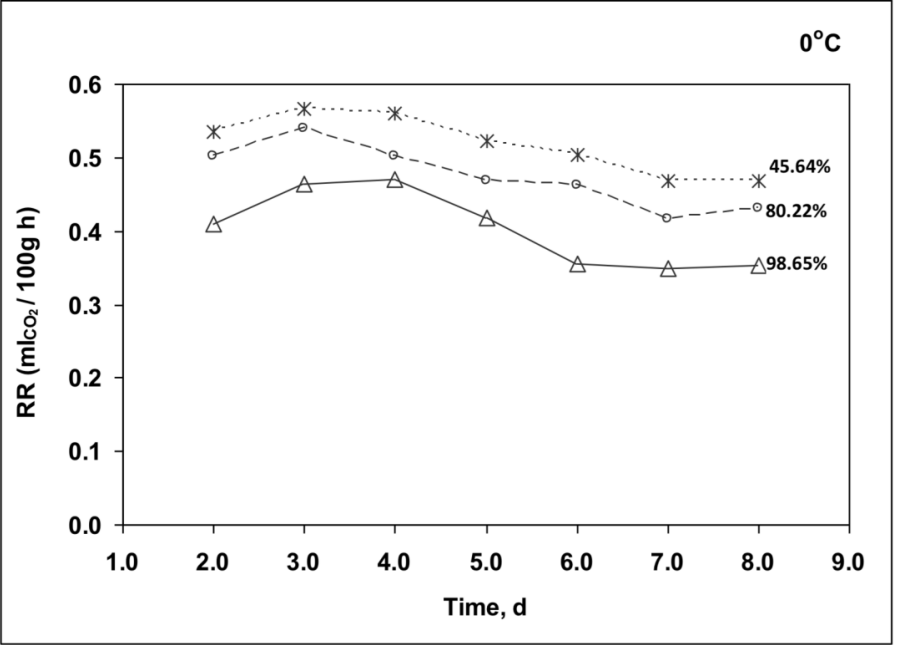

Figure 6. Experimental RR values at $45.64 \%, 80.22 \%$ and $98.65 \%$ relative humidity and $0{ }^{\circ} \mathrm{C}$. Each point is the average of $\mathrm{n}=3$ samples.

Table 1. Analysis of variance (ANOVA) of RR with the experimental factors of relative humidity, storage temperature and time.

\begin{tabular}{lccc}
\hline \multicolumn{1}{c}{ Source } & df & F-ratio & P-value \\
\hline Main effects & & & \\
A: storage temperature & 2 & 2177 & $\leq 0.001^{*}$ \\
B: storage time & 7 & 1.35 & 0.2428 \\
C: relative humidity & 3 & 5.88 & $0.0014^{*}$ \\
Residual & 59 & & \\
Total & 71 & & \\
\hline
\end{tabular}

$*$ = significant at $\mathrm{P} \leq 0.05, \mathrm{df}=$ degree of freedom, All F-ratios are based on the residual mean square error.

\subsection{Analysis of water loss due to transpiration and respiration}

The water loss as it is calculated as $\mathrm{TR}_{\mathrm{m}}$ and $\mathrm{TR}_{\mathrm{s}}$, contains the water loss due to water vapour pressure deficit taken as a physical phenomenon, as well as due to figs respiration taken as a physiological phenomenon. Separation of these two sources of water loss is taking place calculating initially the water loss due to aerobic respiration from Equation 3 and then subtracting it from the respective $\mathrm{TR}_{\mathrm{m}}\left(\mathrm{g} \mathrm{kg}^{-1} \mathrm{~h}^{-1}\right)$. The contribution of the two sources of water loss to the overall $\mathrm{TR}_{\mathrm{m}}$ is presented in Figure 7 where the significance of the water loss due to aerobic respiration is seen at $20^{\circ} \mathrm{C}$ due to a higher respiration rate compared to the respective respiration rate of $10^{\circ} \mathrm{C}$ and $0^{\circ} \mathrm{C}$, regardless the relative humidity. Saltveit (1996) classified several fruits and vegetables based on their respiration rate at $5^{\circ} \mathrm{C}$ and ranked figs as moderate respiring products having $0.5-0.8 \mathrm{~mL}_{\mathrm{CO} 2} 100 \mathrm{~g}^{-1}$ $\mathrm{h}^{-1}$. Differences in respiration rate are expected among different fruit varieties and the maturity stage being harvested. In the present study, the mean respiration rate at $0^{\circ} \mathrm{C}$ was $0.47 \pm 0.08 \mathrm{~mL}_{\mathrm{CO} 2} 100 \mathrm{~g}^{-1} \mathrm{~h}^{-1}$.

Quantification of the two sources of water loss showed that at $20^{\circ} \mathrm{C}$ and saturation case, the water loss 
due to respiration accounts for $3.9 \%$ of the respective water loss due to water vapour deficit. At $0^{\circ} \mathrm{C}$ and saturation (recommended storage conditions) the water loss due to respiration accounts for $2.6 \%$ of the respective water loss due to water vapour deficit. On average, at $0^{\circ} \mathrm{C}, 10^{\circ} \mathrm{C}$ and $20^{\circ} \mathrm{C}$ the water loss due to respiration accounts for the $1.5 \%, 2.1 \%$ and $2.6 \%$ respectively of water loss due to water vapour deficit. Compared to Xanthopoulos et al. (2017) results regarding water loss of pears due to respiration and transpiration, can be seen that although the respiration rate of pears was close to figs respiration rate at $0^{\circ} \mathrm{C}$ $\left(0.48 \pm 0.1 \mathrm{~mL}_{\mathrm{CO} 2} 100 \mathrm{~g}^{-1} \mathrm{~h}^{-1}\right)$, both fruits are very perishable characterised by low storability, the water loss of figs due to water vapour deficit was much higher. This fact highlights the role that plays in the biology and anatomy of the flesh and peel structure of each fruit and how this facilitates the water transfer due to water vapour deficit from fruit flesh to its surroundings. At this point should be acknowledged that figs' ostiole at the bottom of the syconium facilitates the water vapour transport from the inner of the fruit, where female flowers are lined up on the syconium wall, to its surroundings.

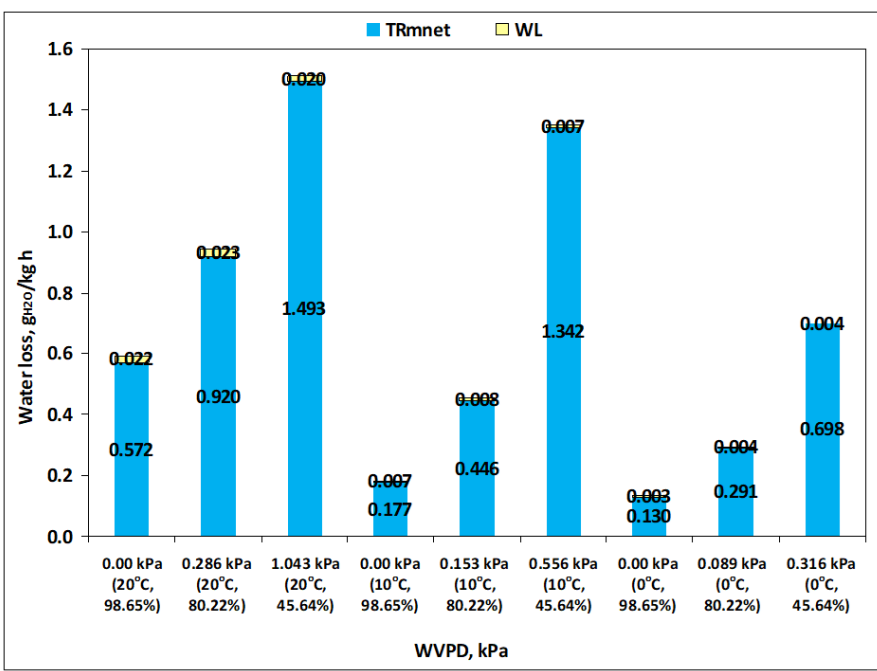

Figure 7. Cumulative histogram of the experimental net water loss due to transpiration $\left(\mathrm{TR}_{\mathrm{m}}\right.$ net $\left.=\mathrm{TR}_{\mathrm{m}}-\mathrm{WL}\right)$ and due to respiration vs the WVPD.

\subsection{Estimation of transpiration coefficient in the analytical transpiration model}

Although the transpiration coefficient $\left(\mathrm{k}_{\mathrm{t}}\right)$ varies linearly with WVPD, in the form of TR $=\mathrm{k}_{\mathrm{t}} \times \mathrm{WVPD}$, where $\mathrm{k}_{\mathrm{t}}$ is the transpiration coefficient per unit area $\left(\mathrm{TR}_{\mathrm{s}}\right)$ or per unit of initial mass $\left(\mathrm{TR}_{\mathrm{m}}\right)$, a deviation is observed at saturation (WVPD $\approx 0.0$ ), as was found in the present study, $\mathrm{TR}_{\mathrm{s}}=0.322 \mathrm{mg} \mathrm{cm}^{-2} \mathrm{~h}^{-1}$ (cf. Figure 3) and in other studies (Xanthopoulos et al., 2014; Xanthopoulos et al., 2017; Bovi et al., 2018) during cold storage of grape tomatoes where $\mathrm{TR}_{\mathrm{s}}=0.007 \mathrm{mg} \mathrm{cm}^{-2} \mathrm{~h}^{-1}$, cold storage of strawberries where $\mathrm{TR}_{\mathrm{m}}=0.0057-0.1737$ $\mathrm{g} \mathrm{kg}^{-1} \mathrm{~h}^{-1}$ and cold storage of pears where $\mathrm{TR}_{\mathrm{s}}=0.054 \mathrm{mg}$ $\mathrm{cm}^{-2} \mathrm{~h}^{-1}$. In the present study, the difference between air temperature at saturation and figs' surface was $1.8^{\circ} \mathrm{C}$ at $0^{\circ} \mathrm{C}, 0.9^{\circ} \mathrm{C}$ at $10^{\circ} \mathrm{C}$ and $0.2^{\circ} \mathrm{C}$ at $20^{\circ} \mathrm{C}$. This point deserves further investigation to identify the source of this discrepancy and the factors that affect it. Bovi et al. (2018) came up to the same conclusion regarding the calculation of transpiration rate during cold storage of strawberries based on WVPD due to increase of surface temperature, the heat of respiration, substrate loss of carbon loss. The water vapour production due to respiration was estimated and respiration and transpiration were associated, quantifying the water loss due to water vapour pressure deficit and respiration with special mention to the saturation case. The transpiration coefficient $\left(\mathrm{k}_{\mathrm{t}}\right)$ is considered as the sum of two coefficients representing the resistance to water transport due to the product's peel $\left(\tau / D_{v} \varphi\right)$ (where $D_{v}$ is the diffusion coefficient of water vapour in the air) and to the adjacent diffusive boundary layer $\left(1 / \mathrm{k}_{\mathrm{a}}\right)$. Peel thickness $(\tau)$ and the fraction of surface area containing pores $(\varphi)$ is difficult to be estimated while relevant information in the literature is scarce. Therefore, an alternative form of the peel resistance was proposed, in which all the parameters are lumped into the $1 / k_{\mathrm{s}}$ parameter which stands for the peel diffusion resistance to water vapour transport having the same units as $1 / \mathrm{k}_{\mathrm{a}}$.

According to Xanthopoulos et al. (2012a), the airfilm mass transfer coefficient was estimated from a Sherwood-Reynolds-Schmidt correlation for a sphere. Considering negligible the flow around the product (i.e., $\mathrm{Re} \rightarrow 0$, where $\mathrm{Re}$ is the Reynolds number), $\mathrm{k}_{\mathrm{a}}$ is estimated as:

$$
\mathrm{k}_{\mathrm{a}}=\frac{\mathrm{D}_{\mathrm{v}}}{\operatorname{T\times r}_{e} \times \mathrm{R}_{\mathrm{v}}}
$$

where $D_{v}$ is the diffusion coefficient of water vapour in the air $\left(\mathrm{m}^{2} \mathrm{~s}^{-1}\right), \mathrm{T}$ is the surrounding air temperature $(\mathrm{K}), \mathrm{r}_{\mathrm{e}}$ is the effective radius of the product (Equation $4 \mathrm{~b}$ ) (m) and $R_{v}$ is the specific gas constant of water vapour $\left(461.89 \mathrm{~J} \mathrm{~kg}^{-1} \mathrm{~K}^{-1}\right)$. For the tested experimental cases, the range of $\mathrm{k}_{\mathrm{a}}$ values was $2.96-3.70 \mathrm{mg} \mathrm{cm}^{-2} \mathrm{~h}^{-1} \mathrm{kPa}^{-1}$ with a mean value of $3.15 \mathrm{mg} \mathrm{cm} \mathrm{cm}^{-2} \mathrm{kPa}^{-1}$. The peel mass transfer coefficient $\left(\mathrm{k}_{\mathrm{s}}, \mathrm{mg} \mathrm{cm} \mathrm{cm}^{-1} \mathrm{kPa}^{-1}\right)$ was calculated from Equation 8,

$$
\mathrm{TR}_{\mathrm{s}}=\frac{\mathrm{WVPD}}{\mathrm{k}_{\mathrm{s}}^{-1}+\mathrm{k}_{\mathrm{a}}^{-1}}
$$

by employing the experimentally estimated values for $\mathrm{TR}_{\mathrm{s}}$ (Equation 1a) and WVPD and substituting the estimated $k_{a}$ values for all the tested cases. For the range of the tested conditions, the $\mathrm{k}_{\mathrm{s}}$ values ranged between 0.0 and $57.38 \mathrm{mg} \mathrm{cm}^{-2} \mathrm{~h}^{-1} \mathrm{kPa}^{-1}$ with a mean value of 12.93 $\mathrm{mg} \mathrm{cm} \mathrm{cm}^{-2} \mathrm{~h}^{-1} \mathrm{Ka}^{-1}$. Rao (2015) presented literature values of $\mathrm{k}_{\mathrm{s}}$ for different fruits and vegetables which ranged 
from 0.04 to $31.43 \mathrm{mg} \mathrm{cm} \mathrm{cm}^{-2} \mathrm{kPa}^{-1}$ (mean value $2.37 \pm 1.0 \mathrm{mg} \mathrm{cm}^{-2} \mathrm{~h}^{-1} \mathrm{kPa}^{-1}$ ). From the reported values is acknowledged the large variability of the peel mass transfer coefficient which in turn shows that $\mathrm{k}_{\mathrm{s}}$ is product dependent and even if it is estimated for similar storage conditions, the variety and maturity stage of the same products are potential sources of $\mathrm{k}_{\mathrm{s}}$ variation.

\section{Conclusion}

The figs mass loss was related to the transpiration and the respiration rate. The lowest WVPD was found in saturation as was expected. Although the WVPD is zero at saturation cases, the noted transpiration rate variation could be respiration driven since the latter is considered in the transpiration rate calculation. The transpiration rate ranged from 0.11 to $1.416 \mathrm{mg} \mathrm{cm}^{-2} \mathrm{~h}^{-1}$ or from 0.13 to $1.513 \mathrm{~g} \mathrm{~kg} \mathrm{k}^{-1} \mathrm{~h}^{-1}$ for the tested cases. Transpiration rate increases with storage temperature, especially from $10^{\circ} \mathrm{C}$ to $20^{\circ} \mathrm{C}$ and decreases with increasing relative humidity from 80.22 to $98.65 \%$. The estimated average respiration rate was $2.69 \pm 0.17 \mathrm{~mL}_{\mathrm{CO} 2} 100 \mathrm{~g}^{-1} \mathrm{~h}^{-1}$ at $20^{\circ} \mathrm{C}, 0.94 \pm 0.11$ $\mathrm{mL}_{\mathrm{CO} 2} 100 \mathrm{~g}^{-1} \mathrm{~h}^{-1}$ at $10^{\circ} \mathrm{C}$ and $0.47 \pm 0.08 \mathrm{~mL}_{\mathrm{CO} 2} 100 \mathrm{~g}^{-1} \mathrm{~h}^{-1}$ at $0^{\circ} \mathrm{C}$. Modelling of the respiration rate was based on an Arrhenius-type equation with good fitting $\mathrm{R}_{\text {adj }}^{2}=0.98$, $\mathrm{SEE}=0.13$. Quantification of the two sources of water loss showed that at $20^{\circ} \mathrm{C}$ and saturation case, the water loss due to respiration accounts for $3.9 \%$ of the respective water loss due to water vapour pressure deficit. At $0^{\circ} \mathrm{C}$ and saturation case, the water loss due to respiration accounts for $2.6 \%$ of the respective water loss due to water vapour pressure deficit. The previous findings can explain that even at very small or close to zero water vapour pressure deficits the water losses still exist. The peel mass transfer coefficient $\mathrm{k}_{\mathrm{s}}$ was calculated from the analytical model of water loss estimation due to transpiration and ranged between 0.0 and $57.38 \mathrm{mg} \mathrm{cm}^{-2} \mathrm{~h}^{-1} \mathrm{kPa}^{-1}$ with the mean value of 12.93 $\mathrm{mg} \mathrm{cm}{ }^{-2} \mathrm{~h}^{-1} \mathrm{kPa}^{-1}$.

\section{Conflict of interest}

The authors declare no conflict of interest.

\section{References}

Ben-Yehoshua, S. and Rodov, V. (2003). Transpiration and water stress. In Bartz, J.A. and Brecht, J.K. (Eds). Postharvest physiology and pathology of vegetables, p. 119-173. New York, USA: CRC Press. https://doi.org/10.1201/9780203910092.ch5

Bovi, G.G., Caleb, O.J., Linke, M., Rauh, C. and Mahajan, P.V. (2016). Transpiration and moisture evolution in packaged fresh horticultural produce and the role of integrated mathematical models: a review. Biosystems Engineering, 150, 24-39. https:// doi.org/10.1016/j.biosystemseng.2016.07.013

Bovi, G.G., Rux, G., Caleb, O.J., Herppich, W.B., Linke, M., Rauh, C. and Mahajan, P.V. (2018). Measurement and modelling of transpiration losses in packaged and unpackaged strawberries. Biosystems Engineering, 174, 1-9. https:// doi.org/10.1016/j.biosystemseng.2018.06.012

Caleb, O.J., Mahajan, P.V., Al-Said, F.A. and Umezuruike, L.O. (2013). Transpiration rate and quality of pomegranate arils as affected by storage conditions. CyTA-Journal of Food, 11(3), 1-9. https://doi.org/10.1080/19476337.2012.721807

Caleb, O.J., Mahajan, P.V., Opara, U.L. and Witthuhn, C.R. (2012). Modelling the respiration rates of pomegranate fruit and arils. Postharvest Biology and Technology, 64(1), 49-54. https://doi.org/10.1016/ j.postharvbio.2011.09.013

Colelli, G., Mitchell, F.G. and Kader, A.A. (1991). Extension of postharvest life of Mission figs by $\mathrm{CO}_{2-}-$ enriched atmospheres. HortScience, 26(9), 11931195. https://doi.org/10.21273/HORTSCI.26.9.1193

Crisosto, H., Ferguson, L., Bremer, V., Stover, E. and Colelli, G. (2011). Fig (Ficus carica L.). In Yahia E.M. (Ed). Postharvest biology and technology of tropical and subtropical fruits, p. 134-160e. Cambridge, United Kingdom: Woodhead Publishing Ltd. https://doi.org/10.1533/9780857092885.134

Dollahite, S., Bremer, V., Crisosto, G.M., Crisosto, C.H., Stover, E. and Ferguson, L. (2007). Effects of delayed cooling on two fresh fig cultivars. Retrieved on February 4, 2019 from University of California, Website: http://groups.ucanr.org/freshfi g/index.cfm, Report.

Gustavsson, J., Cederberg, C. and Sonesson, U. (2011). Global food losses and food waste - Extent, causes and prevention. Retrieved on January 5, 2021 from FAO Website: http://www.fao.org/3/mb060e/ mb060e00.htm, Report.

Greenspan, L. (1977). Humidity fixed points of binary saturated aqueous solutions. Journal of Research of the National Bureau of Standards [A]: Physics and Chemistry, 81A, 89-96. https://doi.org/10.6028/ jres.081A.011

Kader, A. and Saltveit, M. (2003). Respiration and gas exchange. In Bartz, J.A. and Brecht, J.K. (Eds). Postharvest physiology and pathology of vegetables, p. 7-32. New York, USA: CRC Press. https:// doi.org/10.1201/9780203910092.ch2

Lipinski, B., Hanson, C., Lomax, J., Kitinoja, L., Waite, R. and Searchinger, T. (2013). Creating a sustainable food future: reducing food loss and waste. 
Washington, D.C., USA: World Resource Institute.

Lufu, R., Ambaw, A. and Opara, U.L. (2020). Water loss of fresh fruit: Influencing pre-harvest, harvest and postharvest factors. Scientia Horticulturae, 272, 109519. doi.org/10.1016/j.scienta.2020.109519. https://doi.org/10.1016/j.scienta.2020.109519

Mahajan, P.V., Oliveira F.A.R. and Macedo, I. (2008). Effect of temperature and humidity on the transpiration rate of the whole mushrooms. Journal of Food Engineering, 84(2), 281-288. https:// doi.org/10.1016/j.jfoodeng.2007.05.021

Mason, R.L., Gunst, R.F. and Hess, J.L. (2003). Statistical design and analysis of experiments: with applications to engineering and science. New York, USA: Wiley-Interscience,. $\quad$ https:// doi.org/10.1002/0471458503

Mitropoulos, D., Lamprinos, G., and Manolopoulou, H. (2000). A portable setup for fruit respiration measurement. In Gil M. and Artes F.C. (Eds). Improving postharvest technologies of fruits, vegetables and ornamentals, p. 926-931. Murcia, Spain: International Institute of Refrigeration.

Pereira, C., López, C.M., Martín, A., Rivera, M.C., Córdoba, M. and Serradilla, M. (2017). Physicochemical and nutritional characterization of Brebas for fresh consumption from nine fig varieties (Ficus carica L.) grown in Extremadura (Spain). Journal of Food Quality, 2017, 6302109. https:// doi.org/10.1155/2017/6302109

Rao, C.G. (2015). Engineering for storage of fruits and vegetables. Cold storage, controlled atmosphere storage, modified atmosphere storage. $1^{\text {st }}$ ed. India: BS Publications.

Saltveit, M.E. (1996). Physical and physiological changes in minimally processed fruits and vegetables. In Tomás-Barberán, F.A. (Ed.). Phytochemistry of Fruit and Vegetables, p. 205-220. New York, USA: Oxford University Press.

Sastry, S.K. and Buffington, D.E. (1982). Transpiration rates of stored perishable commodities: A mathematical model and experiments on tomatoes. ASHRAE Transactions, 88(1), 159-184.

Sastry, S.K. and Buffington, D.E. (1983). Transpiration rates of stored perishable commodities: A mathematical model and experiments on tomatoes. International Journal of Refrigeration, 6(2), 84-96. doi.org/10.1016/0140-7007(83)90050-6. https:// doi.org/10.1016/0140-7007(83)90050-6

Slatnar, A., Klancar, U., Stampar, F. and Veberic, R. (2011). Effect of drying of figs (Ficus carica L.) on the contents of sugars, organic acids, and phenolic compounds. Journal of Agricultural and Food
Chemistry, 59(21), 11696-11702. https:// doi.org/10.1021/jf202707y

Sousa-Gallagher, M.J., Mahajan, P.V. and Mezdad T. (2013). Engineering packaging design accounting for transpiration rate: Model development and validation with strawberries. Journal of Food Engineering, 119 (2), 370-376. https://doi.org/10.1016/ j.jfoodeng.2013.05.041

Veberic, R., Jakopic, J. and Stampar, F. (2008). Internal fruit quality of figs (Ficus carica L.) in the northern Mediterranean region. Italian Journal of Food Science, 20, 255-262.

Veraverbeke, E.A., Verboven, P., Oostveldt, V.O. and Nicolai, B.M. (2003). Prediction of moisture loss across the cuticle of apple (Malus sylvestris subsp. Mitis (Wallr.)) during storage: part 2. Model simulations and practical applications. Postharvest Biology and Technology, 30(10), 89-97. https:// doi.org/10.1016/S0925-5214(03)00082-6

Xanthopoulos, G., Athanasiou, A., Lentzou, D., Boudouvis, A. and Lambrinos, Gr. (2014). Modelling of transpiration rate of grape tomatoes. Semi-empirical and analytical approach. Biosystems Engineering, 124, 16-23. https://doi.org/10.1016/ j.biosystemseng.2014.06.005

Xanthopoulos, G., Koronaki, E.D. and Boudouvis, A.G. (2012a). Mass transport analysis in perforationmediated modified atmosphere packaging of strawberries. Journal of Food Engineering, 111(2), 326-329.

https://doi.org/10.1016/ j.jfoodeng.2012.02.016

Xanthopoulos, G., Yanniotis, S. and Talaiporou, E. (2012b). Influence of salting on drying kinetics and water diffusivity of tomato halves. International Journal of Food Properties, 15(4), 847-863. https:// doi.org/10.1080/10942912.2010.506018

Xanthopoulos, G.T., Templalexis, C.G., Aleiferis, N.P. and Lentzou, D.I. (2017). The contribution of transpiration and respiration in water loss of perishable agricultural products: The case of pears. Biosystems Engineering, 158, 76-85. https:// doi.org/10.1016/j.biosystemseng.2017.03.011 